\title{
Does Urquhart's Law hold for consortial use of electronic journals?
}

\author{
Yaşar Tonta $\cdot$ Yurdagül Ünal
}

Received: 1 December 2009/Published online: 13 January 2010

(C) Akadémiai Kiadó, Budapest, Hungary 2010

\begin{abstract}
This paper tests the validity of Urquhart's Law ("the inter-library loan demand for a periodical is as a rule a measure of its total use"). It compares the use of print journals at the Turkish Academic Network and Information Center (ULAKBIM) with the consortial use of the same journals in their electronic form by the individual libraries making up the Consortium of Turkish University Libraries (ANKOS). It also compares the on-site use of electronic journals at ULAKBIM with their consortial use at ANKOS. About 700 thousand document delivery, in-house and on-site use data and close to 28 million consortial use data representing seven years' worth of downloads of full-text journal articles were used. Findings validate Urquhart's Law in that a positive correlation was observed between the use of print journals at ULAKBIM and the consortial use of their electronic copies at ANKOS. The on-site and consortial use of electronic journals was also highly correlated. Both print and electronic journals that were used most often at ULAKBIM tend to get used heavily by the member libraries of ANKOS consortium, too. Findings can be used in developing consortial collection management policies and negotiate better consortial licence agreements.
\end{abstract}

Keywords Urquhart's Law · e-Journals · Consortial use · Interlibrary use · Intralibrary use $\cdot$ Supralibrary use

This is a slightly revised version of the paper presented at ISSI 2009 and appeared in In Birger Larsen \& Jacqueline Leta, Proceedings of ISSI 2009-the 12th International Conference of the International Society for Scientometrics and Informetrics, Rio de Janeiro, Brazil, July 14-17, 2009. Vol. 2 (pp. 607-618). Rio de Janeiro: BIREME/PAHO/WHO and Federal University of Rio de Janeiro, 2009.

Y. Tonta $\cdot$ Y. Ünal $(\bowtie)$

Department of Information Management, Hacettepe University, Beytepe, 06800 Ankara, Turkey e-mail: yurdagul@hacettepe.edu.tr

Y. Tonta

e-mail: tonta@hacettepe.edu.tr 


\section{Introduction}

As the Internet and the Web removed the temporal and spatial barriers, users can get access to electronic information sources on a $24 / 7$ basis using the web sites of their libraries. Users no longer have to travel to the library to make use of, say, journals. They can simply get access to their library's web site using a wide variety of computers (desktops, laptops, palmtops, PDAs) or mobile telephones and download the articles they need from electronic journals (e-journals). From their point of view, it makes no difference whatsoever if a journal article they wish to download sits on a campus server or on a publisher's web site half-way around the world.

Libraries strive to meet the information needs of their users by means of using scarce resources and managing them effectively through library consortia. Managing collections has become a challenge both at the individual library and consortium levels. Individual libraries have suddenly realized that they can no longer decide as to what to license or not to license on their own. The administration of a consortium, on the other hand, was faced with an unenviable task of reconciling diverse licensing needs of individual libraries.

Remote access to information sources has resulted in marked changes in traditional definitions of basic terms used in library and information services. For instance, "supralibrary use" is defined as "the use by patrons of a given library of materials not owned by that library but supplied from the outside through either some form of centralized document delivery or from other libraries by means of interlibrary loan. It is to be contrasted with intralibrary use, which is the use by the patrons of a given library of materials held by that library" (Bensman 2005a, p. 35). Definitions of intra-, inter- and supralibrary use just given got blurred in the digital age. Access to information sources (rather than ownership thereof) has become more important. Licence agreements between publishers and library consortia entitled users to get access to the full-texts of thousands of e-journals through the Web. What, then, should we call remote access to the central repository of e-journals by geographically dispersed users of a library consortium? Such use can be defined as "supralibrary use" because a member library of a consortium does not usually "own" e-journals and physically store them on site but provide remote access to them. It can also be defined as "intralibrary use" because a member library "owns" e-journals as much as any other library does and makes them available on a 24/7 basis along with arrangements with publishers for perpetual access. In other words, "supralibrary use and aggregate intralibrary use are very much the same" (Bensman 2005c, p. 67). However, it makes no difference whatsoever how these terms are defined from the users' point of view.

The transition from print journals to on-site and stand-alone use of e-journals to the consortial use thereof by members of a nation-wide academic library consortium made it possible to test the validity of Urquhart's Law in the digital age. The Law "specifies that the supralibrary use of ... journals is positively correlated with the number of libraries holding these journals in a system and therefore is a measure of their aggregate use within the library system, including their intralibrary use at the individual libraries of the system" (Bensman 2005a, p. 32). In this paper we test the validity of Urquhart's Law by comparing the in-house use and document delivery use of print journals at the Turkish Academic Network and Information Center (ULAKBIM) with the use of the same journals in their electronic forms by the members of the Consortium of the Turkish University Libraries (ANKOS, or "Consortium"). We also compare ULAKBIM's on-site use of e-journals with their consortial use at ANKOS. 


\section{Literature review}

In a series of papers Bensman (2005a, b, c) reviewed the contributions of the founder of the current-day British Library Document Supply Centre (BLDSC), Donald J. Urquhart, to the library and information science. Urquhart was the first scientist studying probability distributions in library and information services (Bensman 2005d). He studied the use of journals at the Science Museum Library (SML) by the outside organizations in 1956 . He observed "a positive relationship between the number of times a scientific periodical had been loaned by the SML to an external organization and the total number of holdings of this periodical as was given by the British Union Catalogue of Periodicals (BUCOP) for the main libraries of the United Kingdom" (Bensman, 2005d, p. 199). The higher the loans of a journal title in SML, the more UK libraries tended to own it (Urquhart and Bunn 1959, p. 21). In Urquhart's own words, "the inter-library loan demand for a periodical is as a rule a measure of its total use" (Bensman 2005d, p. 209; Urquhart 1959, p. 290).

Urquhart's finding was surprising in that many believed that if more libraries owned a specific journal title, then a central facility such as SML would get fewer requests for that title, only to satisfy the "residual demand". Urquhart concluded that the number of libraries owning a journal title was an indicator of the nation-wide demand for it. That's to say, "the supralibrary use of scientific journals is very similar to their intralibrary use, and both supra- and intralibrary use are parts of overall or aggregate library use" (Bensman 2005d, p. 200). Urquhart also found that a small fraction (10\%) of all SML journals satisfied the large percentage (80\%) of interlibrary loan (ILL) requests (Bensman 2005d, p. 200). One-third of active journal titles, on the other hand, were rarely used, suggesting that holding a copy of such titles in a UK library would be sufficient to satisfy the total use (Urquhart 1959, p. 293).

As the head of the National Lending Library for Science and Technology (NLL), Urquhart used his findings to develop the serials collection of the British Library Lending Division (BLLD), the predecessor of BLDSC, in Boston Spa, UK. There was a consensus that rarely used journal titles should be subscribed to by BLLD. Yet, not everyone agreed that BLLD should replicate the journal holdings of other UK libraries for frequently used titles. Nonetheless, the union catalog (BUCOP) was consulted to identify the journal titles held by the UK libraries and those titles were included in the serials collection of the lending library, in addition to the ones that were not held by any UK libraries (Urquhart and Bunn 1959, p. 22).

Urquhart's findings were replicated in other studies as well. For instance, a positive relationship was observed between the intralibrary use of journals in the Newcastle University Library and the supralibrary use of the same journals in NLL (Urquhart and Urquhart 1976, as cited in Bensman 2005d, pp. 207-209). The Newcastle study confirmed Urquhart's findings in that if a journal title was not requested often by other libraries from NLL, the same title was unlikely to be used very often in the local library. In the US, some 80 thousand ILL requests submitted to the National Library of Medicine (NLM) in 1959 by 1,780 outside organizations were satisfied by less than $12 \%$ (or 4,347) of 37,000 journal titles held by NLM at that time. Some 161 "core" journal titles such as the Lancet and the British Medical Journal satisfied almost $40 \%$ of all requests while rarely used 3,001 titles did only less than $12 \%$ of all requests (Kurth 1962, as cited in Bensman 2005d, pp. 202203).

Successor of Urquhart as the director of BLLD, Maurice Line and his colleagues validated Urquhart's Law in 1975, 1980 and 1983 when they sampled the BLLD's ILL requests. Journal titles that were requested most often from BLLD were used heavily in 
other libraries. Moreover, the relationship observed by Urquhart in 1956 between the NLL use of journals and the number of libraries holding those journals (based on BUCOP records) was corroborated: there was "a definite tendency for those journals used less frequently to be those held by the least number of libraries and vice versa" (Scales 1976, p. 21, as cited in Bensman 2005d, p. 210). (For a more detailed review of relevant studies, see Bensman 2005d.)

\section{Research question}

Although Urquhart's Law has been validated several times for print journals, its validity has not been tested for e-journals used as part of a nation-wide consortial agreement. This study aims to test the conjecture that the frequency of the use of both print and e-journals in a central library is an indicator of their overall value to the patrons of a consortium of academic libraries having electronic access to the same journals.

\section{Research setting, data and method}

ULAKBIM is the central facility providing access to the full-texts of thousands of e-journals and supporting the nation-wide Internet infrastructure of Turkish universities. ULAKBIM also provides (electronic) document delivery services as it has more than 10,000 printed journal titles with backruns going as far back as early 1980s. ANKOS is a library consortium having more than 100 Turkish academic libraries as members. ANKOS was established to facilitate the consortial use of e-journals in Turkey by developing a national site licence. More recently, ULAKBIM has also signed national site licences for several databases on behalf of universities (Tonta and Ünal 2008; Karasözen 2008; Karasözen and Lindley 2004). Thanks to the availability of national site licences for many databases in Turkey, some 11.5 million full-text e-journal articles were downloaded in 2007 (Karasözen 2008).

For the purposes of this study, interlibrary use of a given journal title can be defined as: (1) the number of in-house use of its print copy; (2) the number of its use for document delivery purposes; and (3) the number of downloads from its electronic copy (available through ScienceDirect OnSite, SpringerLink and Wiley InterScience e-journal databases for on-site use only), all by the users of ULAKBIM. (Note that the on-site use of both print and e-journals at ULAKBIM as defined above can also be considered as intralibrary use, although ULAKBIM has no users of its own per se but serves the information needs of outside users.)

The consortial use of a given e-journal by the patrons of a specific ANKOS member can be defined as intralibrary use while its consortial use by all Consortium members constitutes the total use. (Note that intralibrary use as defined can also be considered as supralibrary use, as Consortium members do not own e-journals but provide access to them.) Intralibrary use and total use data come from the consortial use of Elsevier's ScienceDirect, SpringerLink and Wiley InterScience e-journals by the patrons of more than 90 ANKOS members.

Three pieces of data were obtained from ULAKBIM and from the e-journal publishers to test the validity of Urquhart's Law: (1) Interlibrary use data consisting of more than 150,000 uses (for both in-house and document delivery use) of ULAKBIM's print journals that were also available through ScienceDirect OnSite, SpringerLink and Wiley 
InterScience e-journal databases; (2) Interlibrary use data of more than 500,000 full-text articles downloaded from the same databases by ULAKBIM's on-site users (2002-2006); and (3) Intralibrary use data of some 12 million full-text articles downloaded from ScienceDirect, SpringerLink and Wiley InterScience e-journal databases by ANKOS members (2002-2005). A great majority of intralibrary use (ca. 27 million) came from the ScienceDirect database, which provides access to "over a quarter of the world's STM (Science, Technical and Medical) articles" from more than 2,000 scientific journals with high impact factors (ScienceDirect 2009).

Three hypotheses were tested in this study: (1) The number of in-house or document delivery use of a print journal at ULAKBIM (interlibrary use) is positively correlated with the cumulative number of downloads from its electronic version by the users of all Consortium members (total use); (2) The number of in-house or document delivery use of a print journal at ULAKBIM (interlibrary use) is positively correlated with the number of downloads from its electronic version by the users of each Consortium member (intralibrary use); and (3) The number of downloads from a given e-journal by ULAKBIM's on-site users (interlibrary use) is positively correlated with its cumulative number of downloads by all the users of all Consortium members (total use).

In order to test these hypotheses, ranks of journal titles based on their frequencies of inhouse, document delivery, and on-site use of ULAKBIM and the consortial use of ANKOS members were compared using Spearman's rank order correlation coefficient $r$ (rho). Inhouse and document delivery use data belongs to print journals while on-site and consortial use data belongs to e-journals. As the ScienceDirect consortial use statistics were not itemized by each Consortium member, the total use of each e-journal title by all ANKOS members for each year was compared with that of the on-site use at ULAKBIM (interlibrary use). Consortial use of SpringerLink and Wiley InterScience e-journals was compared title by title on a yearly basis for each ANKOS member with on-site use of the same journals at ULAKBIM.

\section{Findings}

The on-site users of ULAKBIM downloaded a total of 548,446 full-text journal articles from ScienceDirect, SpringerLink and Wiley InterScience e-journal databases (20022006) while the users of Consortium members downloaded close to 28 million articles from the same databases (2001-2007) (Table 1). The percentages of articles downloaded from each database by ULAKBIM's on-site users and by the users of Consortium were

Table 1 Full-text article downloads from electronic journal databases

\begin{tabular}{|c|c|c|c|c|c|c|}
\hline \multirow{2}{*}{$\begin{array}{l}\text { Electronic } \\
\text { journal database }\end{array}$} & \multicolumn{3}{|c|}{ Downloads by ULAKBIM on-site users } & \multicolumn{3}{|c|}{ Downloads by ANKOS consortium users } \\
\hline & $\#$ of journals used & $N$ & $\%$ & \# of journals used & $N$ & $\%$ \\
\hline ScienceDirect & 2,115 & 483,140 & 88.1 & 2,097 & $25,145,293$ & 90.1 \\
\hline SpringerLink & 1,001 & 38,700 & 7.1 & 1,779 & $1,715,164$ & 6.1 \\
\hline Wiley InterScience & 440 & 26,606 & 4.8 & 470 & $1,055,741$ & 3.8 \\
\hline Total & 3,556 & 548,446 & 100.0 & 4,346 & $27,916,198$ & 100.0 \\
\hline
\end{tabular}

Publishers of a few journal titles may have changed between 2001 and 2007 
Table 2 Number of journals satisfying $50 \%$ and $80 \%$ of download requests

\begin{tabular}{|c|c|c|c|c|c|c|c|c|c|c|c|c|}
\hline \multirow[b]{3}{*}{$\%$} & \multicolumn{4}{|c|}{ ScienceDirect } & \multicolumn{4}{|c|}{ SpringerLink } & \multicolumn{4}{|c|}{ Wiley InterScience } \\
\hline & \multicolumn{2}{|c|}{ ULAKBİM } & \multicolumn{2}{|c|}{ ANKOS } & \multicolumn{2}{|c|}{ ULAKBİM } & \multicolumn{2}{|c|}{ ANKOS } & \multicolumn{2}{|c|}{ ULAKBİM } & \multicolumn{2}{|c|}{ ANKOS } \\
\hline & $N$ & $\%$ & $N$ & $\%$ & $N$ & $\%$ & $N$ & $\%$ & $N$ & $\%$ & $N$ & $\%$ \\
\hline 50 & 205 & 9.7 & 208 & 9.9 & 45 & 4.5 & 91 & 5.1 & 30 & 6.8 & 45 & 9.6 \\
\hline 80 & 617 & 29.2 & 602 & 28.7 & 172 & 17.2 & 337 & 18.9 & 100 & 22.7 & 147 & 31.3 \\
\hline
\end{tabular}

similar. The vast majority (about 90\%) of downloaded articles came from Elsevier's ScienceDirect database.

The number of titles available through each journal package and used by ULAKBIM and the Consortium varies. It should be noted that the number of Consortium members licensed to use each database also varied (ScienceDirect: about 90 members in 2007; SpringerLink: 76 in 2007; and, Wiley InterScience: 48 in 2006). Nevertheless, ScienceDirect has been the most heavily used e-journal package in Turkey, constituting more than half the total use from about 35 databases available to Turkish universities (Tonta and Ünal 2008).

Download statistics of ULAKBIM and the Consortium show that relatively few journals satisfied the large percentages of both on-site and consortial demand for three e-journal databases (Table 2; Fig. 1). For instance, 205 and 208 ScienceDirect journals (less than $10 \%$ of all titles) satisfied half the demand of both ULAKBIM's on-site users and ANKOS' consortial users, respectively. Similarly, 45 (out of 1,001) SpringerLink journals and 30 (out of 440) Wiley InterScience journals satisfied half the on-site demand. The number of e-journal titles satisfying half the consortial demand was not much higher (91 Springer and 45 Wiley e-journals). Findings are consistent with those of other studies (e.g., Gatten and Sanville 2004; Ke et al. 2002; Nicholas et al. 2006).

Note that the distributions of journals satisfying on-site and consortial use do not differ much. In fact, the two lines for ScienceDirect journals in Fig. 1 are almost

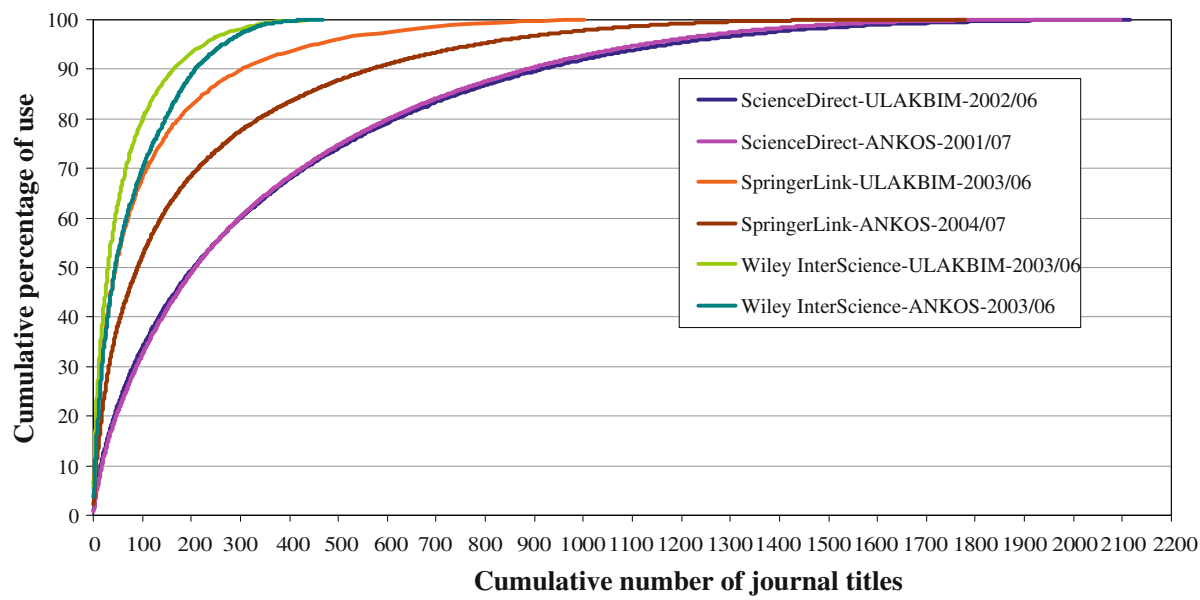

Fig. 1 Distributions of electronic journals satisfying demand 
indistinguishable from each other. It appears that as the total number of downloads increase, distributions of journals satisfying on-site and consortial demand become more alike.

We identified a small number of "core" journal titles that consistently satisfied the bulk of use and the large number of rarely used ones that get almost no use for all three databases. (Core journal titles are usually located in the lower left-hand side of Fig. 1 while the rarely used ones are scattered in the upper middle and upper right-hand side of Fig. 1.) Core journal titles do not fluctuate much on a yearly basis. That's to say, the journal titles that get heavily used for downloads in one year tend to be used heavily in the coming years as well. Spearman rank order correlation coefficients for annual fluctuations of core journal titles ranked by the number of articles downloaded ranged between 0.402 (2001-2002) and 0.874 (2006-2007) for ScienceDirect journals (Table 3). As the number of downloads increased on a yearly basis, the core journal titles seemed to become more stable. This appears to be the case for Wiley InterScience core journal titles as well. SpringerLink core journal titles on the other hand were less stable.

The use of full-text e-journal databases in Turkey has increased steadily over the years (Table 4). Consortium users downloaded seven times (ca. 5.6 million) as many articles in

Table 3 Spearman rank order correlation coefficients for the core journal titles that were common in two consecutive years

a The correlation coefficient for 2006-2007 does not reflect the use of journal titles within the last quarter of 2007

\begin{tabular}{lccc}
\hline & \multicolumn{3}{c}{ Spearman rank order correlation coefficient $(r)$} \\
\cline { 2 - 4 } Years & ScienceDirect & SpringerLink & Wiley InterScience \\
\hline $2001-2002$ & 0.402 & - & - \\
$2002-2003$ & 0.706 & - & - \\
$2003-2004$ & 0.778 & - & 0.556 \\
$2004-2005$ & 0.780 & 0.836 & 0.796 \\
$2005-2006$ & 0.791 & 0.505 & 0.760 \\
$2006-2007$ & $0.874^{\mathrm{a}}$ & 0.781 & - \\
\hline
\end{tabular}

Table 4 Distribution of all downloads by years

\begin{tabular}{|c|c|c|c|c|c|c|c|c|c|c|c|c|}
\hline \multirow[b]{3}{*}{ Year } & \multicolumn{6}{|c|}{ Downloads by ULAKBIM on-site users } & \multicolumn{6}{|c|}{ Downloads by ANKOS consortium users } \\
\hline & \multicolumn{2}{|c|}{ ScienceDirect } & \multicolumn{2}{|c|}{ SpringerLink } & \multicolumn{2}{|l|}{ Wiley } & \multicolumn{2}{|c|}{ ScienceDirect } & \multicolumn{2}{|c|}{ SpringerLink } & \multicolumn{2}{|l|}{ Wiley } \\
\hline & $N$ & $\%$ & $N$ & $\%$ & $N$ & $\%$ & $N$ & $\%$ & $N$ & $\%$ & $N$ & $\%$ \\
\hline 2001 & - & - & - & - & - & - & 810,203 & 3 & - & - & - & - \\
\hline 2002 & 74,322 & 15 & - & - & - & - & $1,362,934$ & 5 & - & - & - & - \\
\hline 2003 & 121,662 & 25 & 7,921 & 20 & 7,367 & 28 & $3,346,381$ & 12 & - & - & 223,280 & 21 \\
\hline 2004 & 109,559 & 23 & 8,532 & 22 & 7,579 & 28 & $4,575,094$ & 17 & 242,333 & 14 & 168,693 & 16 \\
\hline 2005 & 108,581 & 22 & 12,747 & 33 & 5,337 & 20 & $5,264,423$ & 20 & 261,028 & 15 & 270,341 & 26 \\
\hline 2006 & 69,016 & 14 & 9,500 & 25 & 6,323 & 24 & $5,652,780$ & 21 & 483,010 & 28 & 393,427 & 37 \\
\hline 2007 & - & - & - & - & - & - & $5,843,049$ & 22 & 728,793 & 42 & - & - \\
\hline Total & 483,140 & 99 & 38,700 & 100 & 26,606 & 100 & $26,854,864$ & 100 & $1,715,164$ & 99 & $1,055,741$ & 100 \\
\hline
\end{tabular}

The number of downloads from ScienceDirect e-journals by ANKOS users in 2007 does not include the last quarter's use. Similarly, the number of downloads from all three databases by ULAKBIM in 2006 does not include the last quarter's use. Some $20 \%$ of the downloads (or 7,921 articles) did not contain the names of journal titles. Percentages of total use are not $100 \%$ in some columns due to rounding 
2006 as they did back in 2001 from 2,097 different journals contained in the ScienceDirect database. The use of SpringerLink tripled in four years (2004-2007). More than 1.7 million articles were downloaded from 1,779 different SpringerLink e-journals. The rate of increase has been more modest (76\%) for the Wiley InterScience database (2003-2006) (ca. 1 million articles).

The rates of increase in the use of databases by ULAKBIM's on-site users, on the other hand, are not commensurate with those of ANKOS users. On the contrary, it appears that the use of ScienceDirect database has decreased after some fluctuation (from 121,662 in 2003 to 92,102, if the lack of use data for the last quarter of 2006 is taken into account). The use of Wiley InterScience database seems stable while that of SpringerLink increased about $60 \%$. The fact that users have to be at ULAKBIM physically in order to use these databases hinders their use. Walk-in users can get access to ULAKBIM's resources but they cannot get remote access through proxies. It should also be noted that the ScienceDirect database has been available to all Turkish universities through a national site licence since 2006. The number of licensees of SpringerLink and Wiley InterScience databases has gone up over the years, too (SpringerLink: 61 universities in 2004 and 76 in 2007; and Wiley InterScience: 24 in 2003 and 48 in 2006). Obviously, some users no longer needed access to ULAKBIM's copies of these databases once they became available through their own universities.

We provided descriptive statistics on document delivery use of ULAKBIM print journals whose electronic copies were available through ScienceDirect, SpringerLink and Wiley InterScience e-journal databases, along with statistics on the use of these databases by both ULAKBIM on-site users and ANKOS users. We now test the validity of Urquhart's Law. We first compare the use of print journals at ULAKBIM with their consortial use by ANKOS users. We then compare the download statistics that belong to both on-site and consortial use for each title in each e-journal database to find out if the on-site use of an e-journal at ULAKBIM can be taken as an indicator of its overall use by all ANKOS members in Turkey.

Relationship between the use of print journals and consortial use of electronic journals

Data on the use of print journals at ULAKBIM and on the consortial use (total use) of their electronic counterparts by all Consortium members were available for 2002-2005, although the years analyzed vary for each e-journal database. As indicated earlier, the former is based on the traditional use of print journals at ULAKBIM while the latter comes from consortial use statistics of ANKOS members. Print journals used at ULAKBIM were identified on an annual basis and matched with their electronic versions used by Consortium members through ScienceDirect, SpringerLink and Wiley InterScience databases. Thus, commonly used journal titles, albeit in different forms, in the same time periods were filtered. Then, title by title use of print journals at ULAKBIM (interlibrary use) was compared with their consortial use (total use) by ANKOS members using Spearman's rank order correlation coefficient $(r)$.

Descriptive statistics for the matched sets of print and e-journals used by the patrons of ULAKBIM and the Consortium, respectively, are given in Table 5. ULAKBIM satisfied a total of 153,939 in-house and document delivery requests between 2002 and 2005 from print journals whose electronic versions were available through e-journals databases. Consortial use of e-journals during the same period was over 12 million. More than $80 \%$ of ULAKBIM's use and 94\% of ANKOS' use were satisfied from ScienceDirect journals. The percentages of use of Wiley InterScience (11.6\%) and SpringerLink (7.9\%) e-journals 
Table 5 Comparison of print and electronic (consortial) use of journals

\begin{tabular}{|c|c|c|c|c|c|c|c|c|}
\hline \multirow[b]{2}{*}{ Journals } & \multirow[b]{2}{*}{ Time period } & \multicolumn{3}{|c|}{ Print use at ULAKBIM } & \multicolumn{3}{|c|}{ Electronic use by ANKOS } & \multirow[b]{2}{*}{ Spearman's $r$} \\
\hline & & $\begin{array}{l}\text { \# of } \\
\text { journals } \\
\text { used }\end{array}$ & $N$ & $\%$ & $\begin{array}{l}\text { \# of } \\
\text { journals } \\
\text { used }\end{array}$ & $N$ & $\%$ & \\
\hline ScienceDirect & June 2002-Jun. 2005 & 1,384 & 123,893 & 80.5 & 1,864 & $11,450,647$ & 93.8 & 0.489 \\
\hline SpringerLink & Jan. 2004-June 2005 & 282 & 12,151 & 7.9 & 491 & 367,388 & 3.0 & 0.656 \\
\hline Wiley InterScience & Jan. 2003-Dec. 2004 & 215 & 17,895 & 11.6 & 390 & 391,973 & 3.2 & 0.568 \\
\hline Total & & 1,881 & 153,939 & 100.0 & 2,764 & $12,210,008$ & 100.0 & \\
\hline
\end{tabular}

at ULAKBIM were much higher than their consortial use at ANKOS (3.2 and 3.0\%, respectively).

A moderate positive correlation was observed between the print use and consortial use of all three e-journal databases, which proves the first hypothesis of this study and validates Urquhart's Law. The use of a print journal for local needs or for document delivery at ULAKBIM (interlibrary use) can to a certain extent be used as an indicator of the consortial value of its electronic version to all users of ANKOS members (total use).

Relationship between the use of print journals and intralibrary use of electronic journals

As consortial use of ScienceDirect e-journals represent the total use rather than the individual use of each title, it was not possible to compare the use of matched sets of print and e-journals by ULAKBIM users and that by each Consortium member. If the relatively high correlation (Spearman's $r=0.833$ ) between the on-site use of ScienceDirect e-journals at ULAKBIM and their total use by all Consortium members (see below) is taken into account, it can be safely speculated that a positive relationship exists between the use of print journals at ULAKBIM and intralibrary use of their electronic counterparts by many Consortium members.

A total of 1,715,614 full-text articles were downloaded from SpringerLink e-journals by Consortium users. Itemized statistics for each Consortium member representing a total of 367,388 full-text downloads are given in Table 6. The matching process of journals used by the patrons of both ULAKBIM and the Consortium was explained earlier. The large difference between the two figures is primarily due to the fact that use data available for both ULAKBIM and ANKOS did not cover exactly the same periods. (The role of possibly different patterns of journal use should be noted as well.) Eighteen months' worth of both print and electronic use of SpringerLink journals was used to test the validity of Urquhart's Law. As noted earlier, a total of 282 SpringerLink print journals was used to satisfy 12,151 in-house and document delivery requests at ULAKBIM. The average number of journal titles used by both ULAKBIM and Consortium users was 137 ( $S D=73, \min =3$, $\max =222$ ).

The number of use for each print journal at ULAKBIM (interlibrary use) and that for its electronic version by the users of each Consortium member (intralibrary use) were compared. Spearman's rank order correlation coefficients that measure the similarity between the use of print journals at ULAKBIM and the use of their electronic versions by each Consortium member ranged between 0.814 and -0.866 . A positive correlation was 


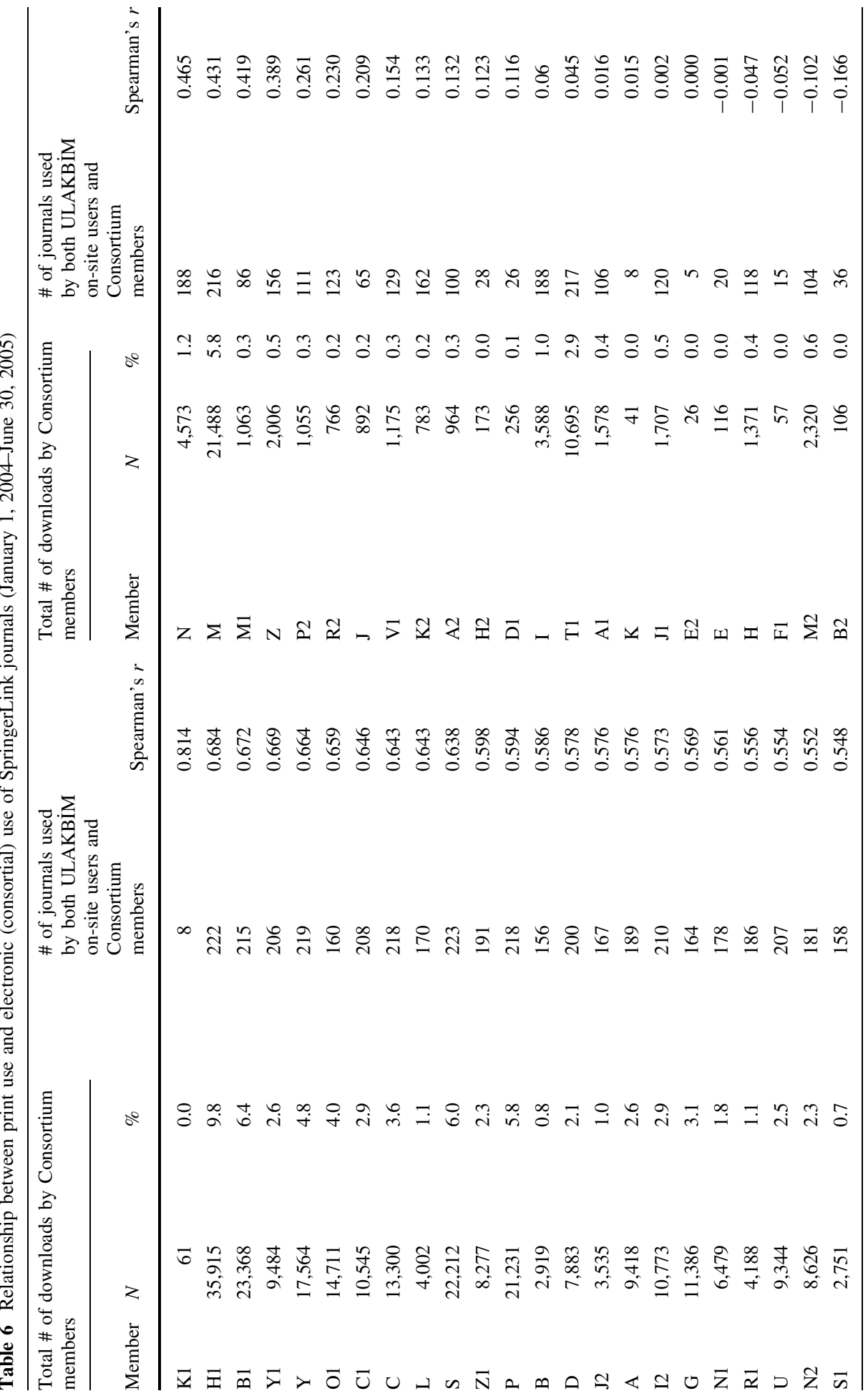




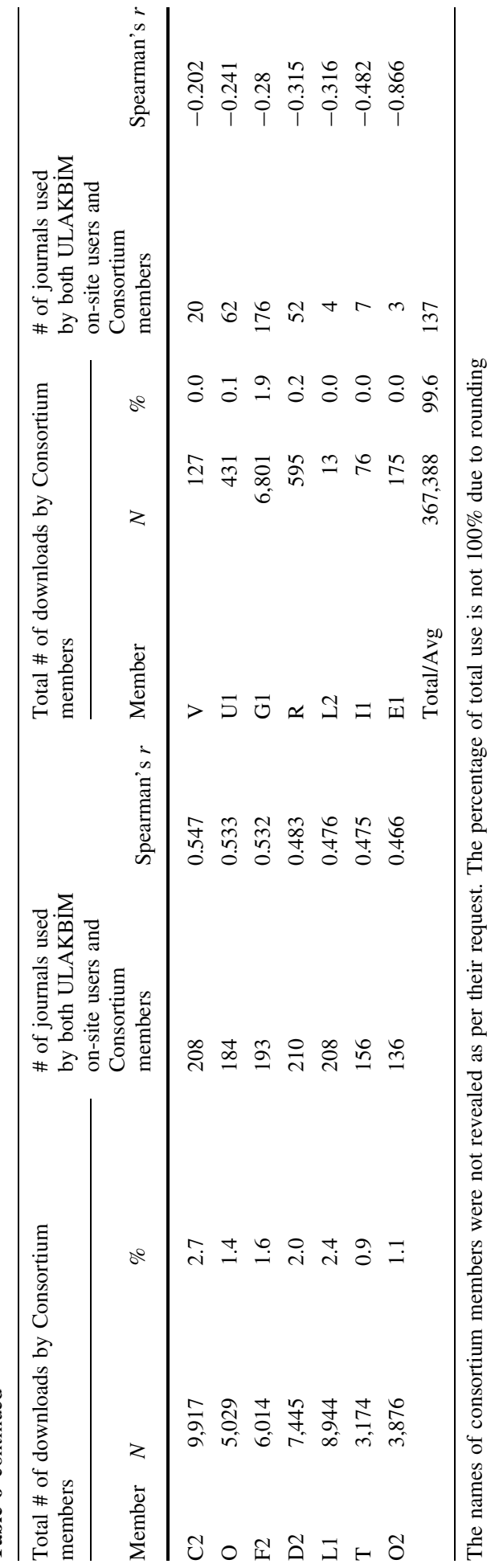


observed between the two for 47 out of 60 Consortium members. They downloaded more than $96 \%$ of all articles from Springer e-journals. Twenty-six Consortium members with correlation coefficients above 0.5 downloaded $75 \%$ of all articles while five members downloaded over one-third of all articles. The total number of downloads by 13 members with zero or negative correlation coefficients, on the other hand, constituted only $4.2 \%$ of all use. The great majority of them (10 out of 13) downloaded articles from a very few SpringerLink journals (between 3 and 62 titles).

The positive correlation observed between print use and consortial use for the vast majority of Consortium members (including the number of total downloads by those members) proves the second hypothesis of this study and validates Urquhart's Law. Print use of a SpringerLink journal at ULAKBIM (interlibrary use) can to a certain extent be used as an indicator of the value of its electronic version to each Consortium member (intralibrary use). Hence, print use also reflects the overall consortial value of e-journal titles to all ANKOS members.

Patrons of Consortium members downloaded a total of 1,055,741 articles from Wiley InterScience journals. Itemized statistics for each member representing a total of 391,973 full-text use are given in Table 7. (The large difference was caused by lack of data for several newly-established universities which became Consortium members in 2006 and 2007.) As noted earlier, a total of 215 Wiley print journals was used to satisfy 17,895 inhouse and document delivery requests at ULAKBIM. The mean number of titles used by both ULAKBIM and Consortium users was $172(S D=41, \min =49$, $\max =208)$. Spearman's rank order correlation coefficients for the relationship between print use and consortial use ranged between 0.664 and -0.2 . Again, a positive correlation was observed for the majority (24) of Consortium members and they downloaded more than $90 \%$ of all full-text articles. Eight members with correlation coefficients above 0.5 downloaded more than $45 \%$ of all articles. The total number of downloads by four Consortium members with negative correlation coefficients, on the other hand, constituted only $9.5 \%$ of all downloads.

Findings for Wiley InterScience e-journal database are a further proof of the second hypothesis of this study. In general, the higher the use of a print journal at ULAKBIM, the greater the number of downloads by the users of each Consortium member from its electronic version (hence, the greater the cumulative number of downloads by all Consortium members). This, once again, validates Urquhart's Law for Wiley InterScience ejournals. The use of print journals (interlibrary use) is an indicator of the value of their electronic versions to both individual members of ANKOS (intralibrary use) and to the whole Consortium (total use).

Relationship between on-site use and consortial use of electronic journals

On-site users of ULAKBIM downloaded a total of 483,140 full-text articles from 2,115 ScienceDirect (2002-2006), 30,779 articles from 1,001 SpringerLink (2004-2006), and 26,606 articles from 440 Wiley InterScience e-journal databases (2003-2006). The corresponding figures for Consortium users were as follows: 20,201,612 full-text articles from 1,948 ScienceDirect, 986,371 articles from 1,351 SpringerLink, and 1,055,740 articles from 470 Wiley InterScience e-journal databases. On-site and consortial use were highly correlated (Spearman's $r$ 's for ScienceDirect, SpringerLink, and Wiley InterScience are $0.833,0.724$, and 0.758 , respectively) (Table 8). Findings suggest that journal titles used heavily at ULAKBIM tend to get used heavily by the Consortium members, too. This proves the third hypothesis of this study and validates Urquhart's Law for consortial use of 
Table 7 Relationship between print use and electronic (consortial) use of Wiley InterScience journals (2003-2004)
The percentage of total use is not $100 \%$ due to rounding

\begin{tabular}{|c|c|c|c|c|}
\hline \multicolumn{3}{|c|}{$\begin{array}{l}\text { Total \# of downloads by } \\
\text { Consortium members }\end{array}$} & \multirow{2}{*}{$\begin{array}{l}\text { \# of journals used } \\
\text { by both ULAKBIM } \\
\text { on-site users } \\
\text { and Consortium } \\
\text { members }\end{array}$} & \multirow{2}{*}{ Spearman's } \\
\hline Member & $N$ & $\%$ & & \\
\hline $\mathrm{U}$ & 11,820 & 3.0 & 153 & 0.664 \\
\hline $\mathrm{O}$ & 26,908 & 6.9 & 208 & 0.650 \\
\hline I1 & 9,119 & 2.3 & 196 & 0.607 \\
\hline $\mathrm{F}$ & 36,673 & 9.4 & 199 & 0.578 \\
\hline V & 31,986 & 8.2 & 208 & 0.562 \\
\hline $\mathrm{N}$ & 47,018 & 12.0 & 207 & 0.557 \\
\hline $\mathrm{J}$ & 2,427 & 0.6 & 152 & 0.516 \\
\hline$S$ & 14,990 & 3.8 & 202 & 0.504 \\
\hline $\mathrm{T} 1$ & 15,860 & 4.0 & 205 & 0.497 \\
\hline $\mathrm{P}$ & 16,579 & 4.2 & 202 & 0.448 \\
\hline A 2 & 10,510 & 2.7 & 200 & 0.445 \\
\hline N1 & 6,047 & 1.5 & 181 & 0.418 \\
\hline $\mathrm{S} 1$ & 15,617 & 4.0 & 190 & 0.412 \\
\hline L1 & 58,792 & 15.0 & 208 & 0.399 \\
\hline G1 & 7,155 & 1.8 & 189 & 0.391 \\
\hline Z & 5,509 & 1.4 & 168 & 0.381 \\
\hline $\mathrm{F} 1$ & 9,763 & 2.5 & 195 & 0.354 \\
\hline $\mathrm{P} 1$ & 201 & 0.1 & 49 & 0.224 \\
\hline $\mathrm{Y}$ & 2,647 & 0.7 & 138 & 0.153 \\
\hline $\mathrm{H}$ & 6,860 & 1.8 & 174 & 0.135 \\
\hline H1 & 2,813 & 0.7 & 169 & 0.092 \\
\hline A1 & 10,781 & 2.8 & 195 & 0.076 \\
\hline $\mathrm{Z} 1$ & 367 & 0.1 & 53 & 0.064 \\
\hline $\mathrm{O} 1$ & 4,471 & 1.1 & 160 & 0.033 \\
\hline M & 3,837 & 1.0 & 139 & -0.074 \\
\hline E1 & 5,338 & 1.4 & 155 & -0.123 \\
\hline G & 3,068 & 0.8 & 138 & -0.132 \\
\hline D1 & 24,817 & 6.3 & 195 & -0.200 \\
\hline Total/Avg & 391,973 & 99.9 & 172 & \\
\hline
\end{tabular}

e-journals. The use of an e-journal in a central facility can be used as an indicator of its total value within a library consortium.

\section{Discussion}

Although the intralibrary use of the matched sets of print and e-journals in libraries has been studied in the past (e.g., Morse and Clintworth 2000), the relationship between traditional use of print journals and consortial use of their electronic versions has not been studied earlier. Findings of this study show that in-house use of print journals or their use for document delivery purposes in a central facility is positively correlated with the 
Table 8 Comparison of on-site and electronic (consortial) use of journals

\begin{tabular}{|c|c|c|c|c|c|c|c|c|}
\hline \multirow[b]{2}{*}{ Journals } & \multirow[b]{2}{*}{$\begin{array}{l}\text { Time } \\
\text { period }\end{array}$} & \multicolumn{3}{|c|}{ On-site use at ULAKBIM } & \multicolumn{3}{|c|}{ Electronic use by ANKOS } & \multirow[b]{2}{*}{ Spearman's $r$} \\
\hline & & $\begin{array}{l}\text { \# of } \\
\text { journals } \\
\text { used }\end{array}$ & $N$ & $\%$ & $\begin{array}{l}\text { \# of } \\
\text { journals } \\
\text { used }\end{array}$ & $N$ & $\%$ & \\
\hline ScienceDirect & 2002-2006 & 2,115 & 483,140 & 89.4 & 1,948 & $20,201,612$ & 90.8 & 0.833 \\
\hline SpringerLink & 2004-2006 & 1,001 & 30,779 & 5.7 & 1,351 & 986,371 & 4.4 & 0.724 \\
\hline Wiley InterScience & 2003-2006 & 440 & 26,606 & 4.9 & 470 & $1,055,740$ & 4.7 & 0.758 \\
\hline Total & & 3,556 & 540,525 & 100.0 & 3,769 & $22,243,723$ & 99.9 & \\
\hline
\end{tabular}

Percentages of total use are not $100 \%$ in some columns due to rounding

nation-wide consortial use of their electronic versions by many libraries. The higher the local use of a print journal, the higher the consortial use (total use) of that journal's electronic version by all consortium members. The local use of print journals is also correlated with the intralibrary use of their electronic counterparts in the majority of consortium members.

Findings of this study also corroborate those of earlier ones with regards to consortial use of e-journals. For instance, the correlation between database use of 20 ANKOS members and that of all ANKOS members was quite high (Spearman's $r=0.7$ and above) (Karasözen et al. 2007). Journal use of large academic libraries with more full-text article downloads was more similar to each other. Also, the use of ScienceDirect e-journals by ANKOS members was more alike than those of SpringerLink and Wiley InterScience e-journals. Similar findings were obtained when the use of these three databases in a large Turkish university library was compared with their total use by all ANKOS members (Özen 2007). A linear relationship was observed between the journal use of the members of the OhioLINK Consortium and that of its largest member (Ohio State University) (Gatten and Sanville 2004). Although journal titles heavily used by each member varied, their patterns of total use of journals were similar. About $35 \%$ of the e-journals in a package satisfied $80 \%$ of all consortial use. Many titles were used rather infrequently by the consortium members.

\section{Conclusion}

Data representing more than 150,000 uses of print journals for traditional purposes, (e.g., document delivery) and more than 500,000 full-text article downloads by ULAKBIM users from ScienceDirect, SpringerLink and Wiley InterScience e-journal databases were compared with that of some 12 million full-text downloads by the Consortium members to test the validity of Urquhart's Law for the consortial use of e-journals. A relatively high positive correlation was observed between the local use of print and e-journals and the total consortial use thereof, indicating that the higher the interlibrary use of a journal title at ULAKBIM, the higher the total use of that title by all Consortium members. Moreover, a small percentage of journal titles in each package satisfies the majority of both on-site and consortial download needs of Turkish academic users. Interlibrary use was also positively correlated with the intralibrary use of e-journals, indicating a similar relationship between the local use of a print or e-journal and its use by each consortium member. Hypotheses of the study were proved and, hence, the question in the title of this paper can be answered: "Urquhart's Law holds for the consortial use of electronic journals". 
Findings of this study can be used in consortial collection development and management. Frequently used journal titles can be retained while rarely used or never used ones should be considered for exclusion from the collection without harming the integrity of the national site licences. Findings can also be used to negotiate better consortial licence agreements with e-publishers. The use data can be analyzed in more detail by taking into account the characteristics of consortium members (universities) such as their size and curricula.

Acknowledgments This study was supported in part by a research grant of the Turkish Scientific and Technological Research Center (SOBAG-106K068). We thank ULAKBIM and publishers for making the use data available; especially Uğur Yılmaz of ULAKBIM, Hatim El Faiz of Elsevier, Zeynep Niksarlı of Swets, and Burcu Keten of Ankara University. We also thank Dr. Stephen J. Bensman of Louisiana State University for his meticulous reading of an earlier version of this paper and for his invaluable suggestions. Any remaining errors are of our own.

\section{References}

Bensman, S. J. (2005a). Urquhart's Law: Probability and the management of scientific and technical journal collections: Part 1. The Law's initial formulation and statistical bases. Science \& Technology Libraries, 26(1), 31-68.

Bensman, S. J. (2005b). Urquhart's Law: Probability and the management of scientific and technical journal collections: Part 2. Probability in the development and management of a central document delivery collection. Science \& Technology Libraries, 26(2), 5-31.

Bensman, S. J. (2005c). Urquhart's Law: Probability and the management of scientific and technical journal collections: Part 3. The Law's final formulation and implications for library systems. Science \& Technology Libraries, 26(2), 33-69.

Bensman, S. J. (2005d). Urquhart and probability: The transition from librarianship to library and information science. Journal of the American Society for Information Science and Technology, 56(2), 189-214.

Gatten, J. N., \& Sanville, T. (2004). An orderly retreat from the big deal: Is it possible for consortia? D-Lib Magazine, 10(10). Retrieved January 16, 2009, from http://www.dlib.org/dlib/october04/gatten/ 10gatten.html.

Karasözen, B. (2008). Consortial usage of electronic journals in Turkey. Paper presented at the 37th LIBER annual general conference, Koç University, Istanbul, July 1-5, 2008. Retrieved January 16, 2009, from http://eprints.rclis.org/14862/1/Turkishunilib.pdf.

Karasözen, B., Kaygusuz, A., \& Özen, H. B. (2007). Patterns of e-journal use within the Anatolian University Library Consortium. Serials, 20(1), 37-42.

Karasözen, B., \& Lindley, J. A. (2004). The impact of ANKOS: Consortium development in Turkey. The Journal of Academic Librarianship, 30, 402-409.

Ke, H.-R., Kwakkelaar, R., Tai, Y.-M., \& Chen, L.-C. (2002). Exploring behavior of e-journal users in science and technology: Transaction log analysis of Elsevier's ScienceDirect OnSite in Taiwan. Library \& Information Science Research, 24, 265-291.

Kurth, W. H. (1962). Survey of the interlibrary loan operation of the National Library of Medicine. Washington, DC: U.S. Department of Health, Education, and Welfare, Public Health Service.

Morse, D. H., \& Clintworth, W. A. (2000). Comparing patterns of print and electronic journal use in an academic health science library. Issues in Science and Technology Librarianship, 28. Retrieved January 16, 2009, from http://www.library.ucsb.edu/istl/00-fall/refereed.html.

Nicholas, D., Huntington, P., Jamali, H. R., \& Tenopir, C. (2006). What deep log analysis tells us about the impact of big deals: Case study OhioLINK. Journal of Documentation, 62, 482-508.

Özen, H. (2007). Elektronik dergilerde kullanım analizi: ANKOS ve ODTÜ örneği. In S. Kurbanoğlu, Y. Tonta \& U. Al (Eds.), Değişen Dünyada Bilgi Yönetimi Sempozyumu, 24-26 Ekim 2007, Ankara, Bildiriler (pp. 201-208). Ankara: Hacettepe Üniversitesi Bilgi ve Belge Yön. Bölümü.

Scales, P. A. (1976). Citation analyses as indicators of the use of serials: A comparison of ranked title lists produced by citation counting and from use data. Journal of Documentation, 31, 17-25.

ScienceDirect. (2009). Retrieved January 18, 2009, from http://www.elsevier.com/wps/find/electronic productdescription.cws_home/622109/description\#description. 
Tonta, Y., \& Ünal, Y. (2008). Consortial use of electronic journals in Turkish universities. In L. Chan \& S. Mornati (Eds.). Open scholarship: Authority, community and sustainability in the age of web 2.0: Proceedings of the 12th international conference on electronic publishing. Toronto, June 25-27, 2008 (pp. 203-216). Toronto: International Conference on Electronic Publishing. Retrieved, January 15, 2009, from http://eprints.rclis.org/14031/1/tonta-unal-elpub-2008-06-26.pdf.

Urquhart, D. J. (1959). Use of scientific periodicals. In Proceedings of the international conference on scientific information, Washington, DC, November 16-21, 1958 (Vol. I, pp. 287-300). Washington, DC: National Academy of Sciences, National Research Council. Retrieved, January 15, 2009, from http://books.nap.edu/openbook.php?record_id=10866\&page=287.

Urquhart, D. J., \& Bunn, R. M. (1959). A national loan policy for scientific serials. Journal of Documentation, 15, 21-37.

Urquhart, J. A., \& Urquhart, N. C. (1976). Relegation and stock control in libraries. Stocksfield, England: Oriel Press. 